\title{
Reclamation of ultra-fine coal with Scenedesmus microalgae and comprehensive combustion property of the Coalgae ${ }^{\circledR}$ composite
}

\author{
Vitus O. Ejesieme ${ }^{1 *}$, Juan Riaza ${ }^{2}$, Nicole Vorster ${ }^{1}$, Gary Dugmore ${ }^{1}$, Ben Zeelie ${ }^{1}$ \\ 1 InnoVenton and the Downstream Chemicals Technology Station, Department of Chemistry, Faculty of Science, \\ Nelson Mandela University, PO Box 77000, Port Elizabeth 6031, South Africa \\ 2 Drax Power Station, Selby, North Yorkshire YO8 8PH, England. \\ ORCiDs: V.O. Ejesieme: https://Orcid.org/0000-0001-5952-6048 J. Riaza: https://Orcid.org/0000-0001-9581-2842 \\ N. Vorster: https://Orcid.org/0000-0002-4529-9435 G. Dugmore: https://Orcid.org/0000-0001-6579-9393
}

\begin{abstract}
Combustion of South African discard ultra-fine coal, charcoal, microalgae biomass, and composites of the three under air were studied. The objective of the study was to determine the effect of Scenedesmus microalgae biomass on the comprehensive combustion characteristics (CCC) of the ultra-fines. The composites were designed with Design Expert and, unlike blending with the dry microalgae biomass, fresh slurry was blended with the ultra-fine coal and charcoal. Non-isothermal combustion was carried out at heating rate of $15^{\circ} \mathrm{C} / \mathrm{min}$ at 40 $900{ }^{\circ} \mathrm{C}$ and flow rate of $20 \mathrm{ml} / \mathrm{min}$, oxygen/ carbon dioxide $\left(\mathrm{O}_{2} / \mathrm{CO}_{2}\right)$ air. Combustion properties of composites were determined from thermogravimetric-differential thermogravimetric analysis and analysed using multiple regression. On combustion, the interaction of coal-charcoal-microalgae was antagonistic ( $b=-1069.49)$, while coal-microalgae $(b=39.17)$, and coal-charcoal $(b=80.37)$, were synergistic $(p=0.0061)$. The coal-microalgae (Coalgae) indicated first order reaction mechanism, unlike coal and the charcoal. The CCC index of Coalgae, $(S$-value $=4.52 E 8)$ was superior relative to ultra-fine ( $S$-value $=3.16 E 8)$, which indicated high-quality fuel. This approach to combusting ultra-fine coal with microalgae biomass is partly renewable, and it would advance the production of heat and electricity.
\end{abstract}

Keywords: kinetics, modelling, optimisation, s-value, synergistic

\section{Highlights}

- Scenedesmus added value to reclamation and combustion of ultra-fine coal.

- The interaction between coal dust and microalgae biomass was synergistic.

- The derived response surface model could predict comprehensive combustion characteristics.

- The combustion kinetic model of Coalgae deviated from first order reaction.

\footnotetext{
Journal of Energy in Southern Africa 31(1): 14-27

DOI: https://dx.doi.org/10.17159/2413-3051/2020/v31i1a6430

Published by the Energy Research Centre, University of Cape Town ISSN: 2413-3051

This work is licensed under a Creative Commons Attribution-ShareAlike 4.0 International Licence

https://journals.assaf.org.za/jesa

Sponsored by the Department of Science and Technology

* Corresponding author: Tel: +234 (0) 706877 7886,

+27 (0) 83858 1839; email: ejevit@yahoo.com
} 


\section{Introduction}

Coal combustion contributed about $38 \%$ of the world's electricity production in 2018 (BP Energy, 2018). The International Energy Agency IEA reported about 888.9 billion tonnes of recoverable coal reserves globally (Africa, 2018), most of them in Australia, China, India, Russia, South Africa and the United States (David, 1995). The 2003 and 2017 IEA statistics on primary energy supply by coal were 2619947 ktoe and 3789934 ktoe respectively. Worldwide combustion was about 2.5 billion tons yearly (Demirba, 2003). South Africa's coal consumption is increasing, as it built the large Medupi power station in 2011 (Rafey et al., 2011). South Africa has about 66700 Mt coal reserve (Campus, 2019), and coal contributes significantly to its foreign exchange earnings (Rosemary, 2013). Combustion of coal contributed about $82 \%$ of South African electricity production in 2018 (Africa, 2018). Coal processing generated 51.8-450 Mt/a of discard coal between 2013 (Rosemary, 2013) and 2014 (Muzenda, 2014). The amount of carbon dioxide $\left(\mathrm{CO}_{2}\right)$ emitted in 2013 and 2017 was $215.587 \mathrm{Mt}$ and 456.000 Mt respectively (Bakhtyar et al., 2014). Combustion of coal cannot be completely avoided without sustainable alternatives. Coal combustion releases $\mathrm{CO}_{2}$, however, microalgae biomass used to make Coalgae, would utilise the $\mathrm{CO}_{2}$ while growing in a photo-bioreactor (Figure 1). This biomass component means that this approach partly comes in the renewable energy category.

Commercial production of microalgae biomass, which can be converted to fuel and valuable chemicals (Filippis et al., 2015), started in 1960 in Japan (Borowitzka, 1999), and now more than 70 companies worldwide produce it (Spolaore et al., 2006). South Africa receives solar radiation of 4 000-6 000 $\mathrm{kw} / \mathrm{h} / \mathrm{m}^{2}$ yearly (Filippis et al., 2015; Munzhedzi et al., 2009), which makes it suitable for production of microalgae biomass, as low cultivation costs were reported in areas with considerable sunlight for systems with optimised growth conditions (Plis et al., 2017). Microalgae biomass could be produced in ponds, tanks, tubes, fermenters and raceways (Borowitzka, 1999).

Ultra-fine coal is often discarded by coal companies as it has no market value, but it can be reclaimed as quality fuel by blending with microalgae biomass. The study approach blended non-dried Scenedesmus microalgae with ultra-fine coal and treated the samples to considerable moisture level for analysis. Scenedesmus microalgae biomass produced in the photo-bioreactor has higher productivity than any other conventional biomass. Scenedesmus microalgae as a plant contains mainly cellulose and hemicellulose (Chen et al., 2013; Burhenne et al., 2013) and it does not depend on arable land for growth. It could bind with discard ultra-fine to reclaim and upgrade the coal fines. The discard ultra-fine of high- and low-quality coal constitutes underground and surface mine environmental hazard. South Africa is rated as $14^{\text {th }}$ largest emitter of $\mathrm{CO}_{2}$ worldwide and reduction of this gas is an international focus (CarbonBrief, 2018). The combustion of only coal at power stations contributed to poor $\mathrm{CO}_{2}$ reduction rating. Microalgae-discard ultra-fine coal combustion can improve South Africa's rating, its economy and primary energy needs - electricity.

Most countries in Europe utilise coal and there are several co-firing facilities there (Jones et al., 2017, Sami et al., 2001a; Pirraglia et al., 2012). The uptake of $\mathrm{CO}_{2}$ by microalgae biomass is high. Microalgae biomass has the potential to grow all-year round and would, therefore, allow its integration with a stationary combustion source. The biomass could be used to upgrade low quality lump coal as well as discard ultra-fine of low- and high-grade coal.

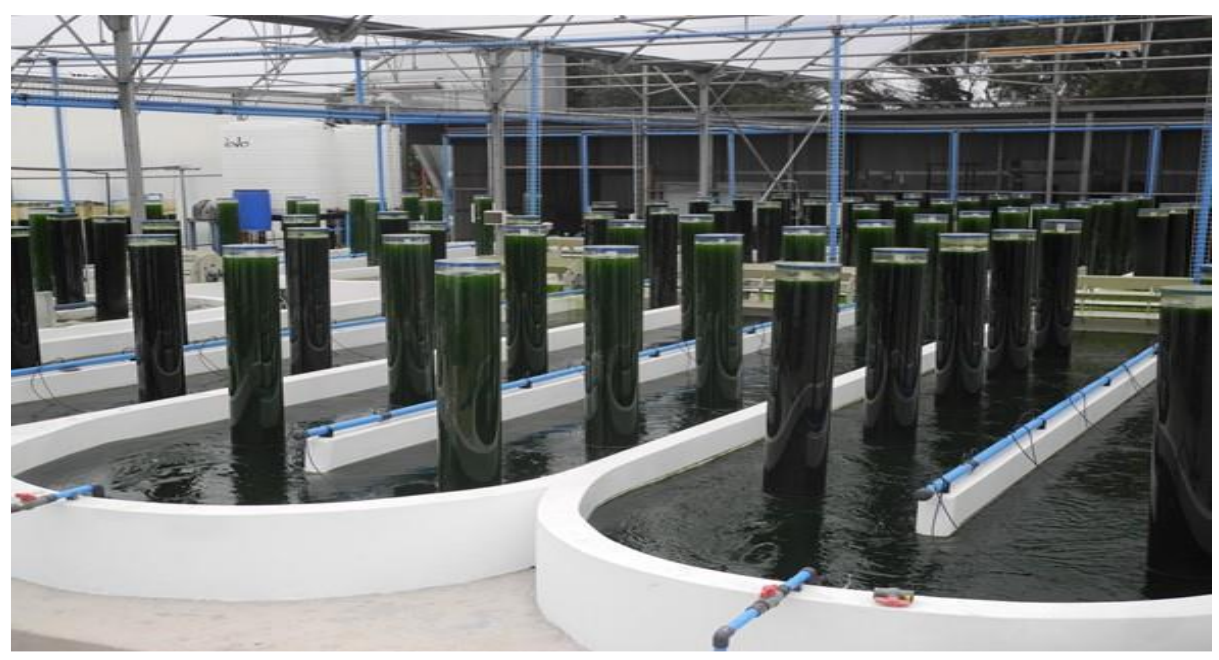

Figure 1: Production of microalgae biomass using photo-bioreactors at InnoVenton, Nelson Mandela University Port Elizabeth, Eastern Cape, South Africa. 
Table 1. Feedstocks and typical chemical composition.

\begin{tabular}{lcc}
\hline \multicolumn{1}{c}{ Feedstocks } & Source & Chemical composition (Subscripts in \%) \\
\hline Discard ultra-fine coal & Eskom & $\mathrm{C}_{75-90} \mathrm{H}_{4.5-5.5} \mathrm{~N}_{1-1.5} \mathrm{~S}_{1-2} \mathrm{O}_{5-20}$ (Joel et al., 2010) \\
Wood charcoal & Charka Ind. & $\mathrm{C}_{100} \mathrm{H}_{85} \mathrm{~N}_{1} \mathrm{~S}_{0.3} \mathrm{O}_{21}$ (Antal, 2003) \\
Microalgae biomass & InnoVenton & $\mathrm{C}_{48-50} \mathrm{H}_{7-9} \mathrm{~N}_{8.7-9} \mathrm{~S}_{0.55-1} \mathrm{O}_{21-30}$ (Spolaore et al., 2006) \\
\hline
\end{tabular}

Table 2. Proximate and ultimate parameters.

\begin{tabular}{lcccccccccc}
\hline \multicolumn{1}{c}{ Samples } & \multicolumn{4}{c}{ Proximate (\%) } & \multicolumn{5}{c}{ Ultimate (\%) } \\
\hline & $\mathrm{I} . \mathrm{M}$ & $\mathrm{V} \mathrm{M}_{\mathrm{daf}}$ & $\mathrm{F} \mathrm{C}_{\text {daf }}$ & $\mathrm{Ash}$ & $\mathrm{E}(\mathrm{MJ} / \mathrm{kg})$ & $\mathrm{C}$ & $\mathrm{H}$ & $\mathrm{N}$ & $\mathrm{S}$ & $\mathrm{O}$ \\
\hline Uncertainty & $( \pm 0.01)$ & $( \pm 0.70)$ & $( \pm 0.25)$ & $( \pm 0.05)$ & - & - & - & - & - & - \\
Ultra-fines & 6.20 & 27.56 & 43.51 & 22.83 & 22.37 & 73.33 & 4.51 & 1.54 & 0.71 & 19.90 \\
Charcoal $^{*}$ & 5.29 & 23.26 & 65.58 & 5.87 & 27.24 & 73.14 & 3.28 & 0.64 & 0.00 & 22.94 \\
Microalgae $^{*}$ & 5.68 & 75.59 & 12.38 & 6.36 & 22.04 & 51.45 & 8.09 & 6.13 & 0.59 & 33.74 \\
Microalgae** $^{* *}$ & 6.33 & 76.21 & 11.58 & 5.88 & 21.07 & 50.95 & 8.13 & 5.98 & 0.61 & 34.34 \\
\hline
\end{tabular}

$\mathrm{I} . \mathrm{M}=$ inherent moisture, $\mathrm{VM}=$ volatile matter, $\mathrm{FC}=$ fixed carbon, $\mathrm{E}=$ higher heating value (HHV) (dry basis), * = oven,

${ }^{* *}=$ freeze dried, $\mathrm{d}$ a $\mathrm{f}=$ dry ash free basis. $\mathrm{C}, \mathrm{H}, \mathrm{N}, \mathrm{S}, \mathrm{O}=$ carbon, hydrogen, nitrogen, oxygen

The IEA Clean Coal Centre reported that about $58 \mathrm{Gt}$ of discard coal are available worldwide, with more added yearly (Jones et al., 2017). South Africa's stockpiled discard ultra-fine coal was estimated at $60 \mathrm{Mt} / \mathrm{a}$, and there are ultra-fine coal reserves of about two billion tons (Bunt et al., 2015).

Microalgae adsorbs onto coal and charcoal (Zeelie et al., 2013; Pirraglia et al., 2012); and $\mathrm{CO}_{2}$ in the flue gas generated from coal fired stations has been used to grow microalgae biomass (Yun et al., 1997; Lee et al., 2002). The sequestration of $\mathrm{CO}_{2}$ in flue gas by microalgae biomass has been established (Packer, 2009). It adds value in terms of the decrease of $\mathrm{CO}_{2}$ emission and $\mathrm{CO}_{2}$ can be limited by the biomass use as a fuel; moreover, $\mathrm{CO}_{2}$ from flue gas can also be captured directly in algae photo-bioreactors. The present study examined the combustion characteristics of the coal-microalgae composite known as Coalgae. It was hypothesised that microalgae biomass would bind with high and low discard ultra-fine coal and upgrade the combustion index (S-value). Discard ultra-fine was used as this would give insight into the interaction of Scenedesmus and ultra-fines derived from low- as well as high-grade coal. The aim of this study is to determine the effect of Scenedesmus microalgae biomass on the comprehensive combustion characteristics (CCC) of the coal ultra-fines. Microalgae is a renewable source of high value chemicals (Spolaore et al., 2006), so blending Scenedesmus with discard ultrafine coal would yield bio-fossil suitable for hydrocarbon chemicals.

\section{Materials and methods 2.1 Feedstock preparation}

The feedstock (Tables 1-2) featured discarded ultra- fine coal supplied by Eskom Izibulo coal mine at Witbank in Mpumalanga province. The Scenedesmus microalgae biomass was harvested from the photo-bioreactor at the InnoVenton greenhouse, while the wood charcoal was produced by Charka. The coal was ball-milled and screened with sieves to achieve 63-45 $\mu \mathrm{m}$ size as in ASTM D-2013. The process was repeated for charcoal.

The Scenedesmus microalgae was grown in a closed photo-bioreactor at InnoVenton, Nelson Mandela University Port Elizabeth, South Africa. The sample was harvested when the mass concentration (density) was 3-5 g/L. It was treated with Westfalia SSD6 centrifuge to achieve solid content of $10-15 \%$, and further concentrated with Hermle Z383 centrifuge, decanted, and distilled water was added to re-disperse resultant wet cake. The process was repeated to obtain clean pellet (cake). Some cleaned pellet was freeze dried to an extent for about 12 hours at $-40{ }^{\circ} \mathrm{C}$. The storage and drying method affect the biomass properties. For example, fresh biomass sample allowed to stand in a bucket staled with time, reducing the binding properties. Then the amount (weight) of dry solid of cleaned biomass pellet was determined and calculated in percent using Smart Trac CEM System -5 at $110^{\circ} \mathrm{C}$.

\subsection{Design of composites and preparation}

The D-optimal mixture design and regression analysis was used to study the material interaction (Bosma, 2012a; Bosma, 2012b). Composites were designed with Design-Expert version 5.0.9, which facilitated estimation of the influence of each proportion of material. A minimum of $70 \%$ coal dust (C), a maximum of $20 \%$ of microalgae biomass (A), and an upper limit of $30 \%$ charcoal $(\mathrm{Ch})$ was used 
in the design. At about $20 \%$ inclusion rate, biomass improves the reactivity of coal considerably (Arias et al., 2008). Charcoal was included to understand in detail the interaction between $\mathrm{A}$ and C. Each composite summed up to 100 or 1 (i.e., \% or fraction). A range of composites that allowed for the calculation of model parameters with a minimum bias was designed. Then $\sim 53.02 \mathrm{~g}$ of coal $\mathrm{C}$ which has $\sim 6.09 \%$ of moisture was added to $\sim 0.154$ litres (i.e., $\sim 28.82$ g) of A. Mass concentration of the Scenedemus biomass was $\sim 187.155 \mathrm{~g} / \mathrm{l}$. The biomass A and coal C was homogenised with mixer for 15 minutes, i.e. Coalgae (Figure 2) powder. Finally, 1.55 g of charcoal $\mathrm{Ch}$ of $\sim 5.17 \%$ moisture was added and all the materials were homogenised for 20 minutes.

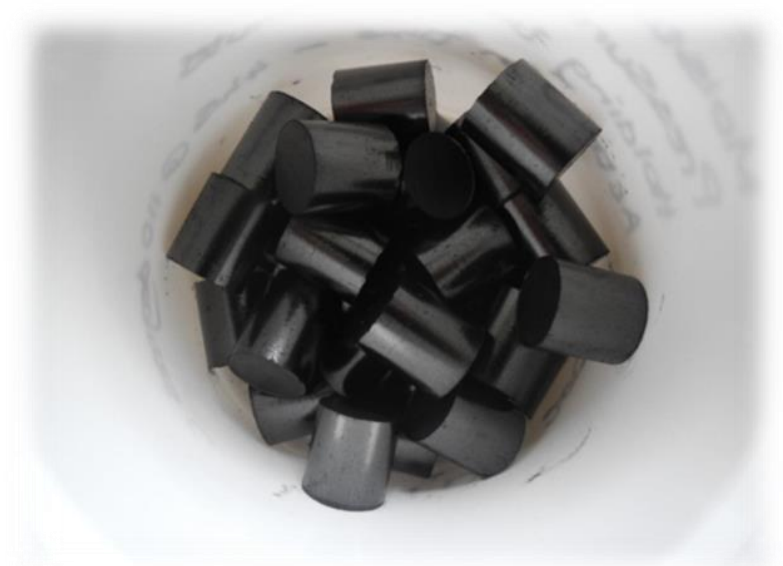

Figure 2: Sample of composites - Coalgae fuel.

The composite was centrifuged at $4500 \mathrm{rpm}$, used to form Coalgae, which was dried at 105-110 ${ }^{\circ} \mathrm{C}$ to 3-5\% moisture. The Coalgae describes a combination of coal and microalgae biomass, which exists as 'one' fuel.

\subsection{Characterisation}

The proximate analysis was determined according to ASTM D-3172-3179 for coal. Moisture was carried out with about $1 \mathrm{~g}$ of each sample in a Gallenkamp OV-330 oven, at $107 \pm 3{ }^{\circ} \mathrm{C}$ for 1 hour. The same mass was loaded in Nabertherm furnace $\mathrm{S}-17$, at $750{ }^{\circ} \mathrm{C}$ for 4 hours for the ash analysis. For the volatile analysis, the sample was incubated at $950 \pm 20^{\circ} \mathrm{C}$ for 7 minutes in the furnace. Fixed carbon content was calculated by difference (James et al., 2005), while the carbon (C), hydrogen (H), nitrogen $(\mathrm{N})$, and sulphur $(\mathrm{S})$ contents were determined by combusting $\sim 5 \mathrm{mg}$ sample in a Vario EL Cube elementar analyser at about $1200^{\circ} \mathrm{C}$. The oxygen content was calculated by difference. Energy content was determined with a Lecco AC600 bomb calorimeter according to the ASTM-D5865-07 method.

The percent particle size of sample as determined using Malvern Master Sizer was $62.74 \mu \mathrm{m}$ for discard ultra-fine coal, $75.73 \mu \mathrm{m}$ for charcoal, while
Scenedemus biomass was assumed to be $<53 \mu \mathrm{m}$ (Xiumin et al., 2001a). Small particle size improved molecular contact, facilitated adsorption of the live microalgae biomass unto the coal and charcoal (Zeelie et al., 2013). The volatile matter per fixed carbon ratio of typical coal is < 1.0 (Baxter, 2010). The proximate analysis for oven or freeze-dried microalgae biomass showed volatile matter per fixed carbon ratio of $>6$. 0 . The ratio of $>4.0$ is typical of other biomass (Baxter, 2005). High volatile matter per fixed carbon ratio could promote a stable flame as a value of $\sim 35 \%$ had the same effect (Baxter, 2005). The Scenedesmus microalgae sample has an approximate composition of $\mathrm{C}_{51.20} \mathrm{H}_{8.11} \mathrm{~N}_{6.05} \mathrm{~S}_{0.60}$

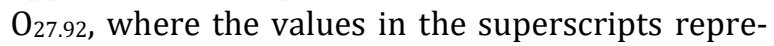
sent quantity as a percentage. The coal dust is denser than microalgae, but the higher heating values are equivalent. As a result, the energy content in the composite would not be compromised given that the composite was well mixed. Therefore, Coalgae could be fired like any other coal-biomass, but as one material. The high $\mathrm{H}$ content in microalgae biomass could increase the volatile content like blends of coal and another biomass (Gil et al., 2010). Freeze drying possibly affected the structure and binding properties of the biomass as indicated by the difference in ultimate analysis results. The high oxygen content in this biomass would enhance the oxidation of the blend.

\subsection{Thermogravimetric analysis}

The thermogravimetric analyser (TGA) is widely accepted to provide valuable information for coal characterisation (Syed et al., 2011). About $10 \mathrm{~g}$ of ground sample was dried in a Gallenkamp OV-330 oven at $105{ }^{\circ} \mathrm{C}$ for 2 hours and cooled for 15 minutes. Then, $5 \mathrm{mg}$ of sample was weighed into an aluminium crucible on Mettler Toledo Stare version 6, TG 851 furnace microbalance and initial weight was recorded. The TGA combustion conditions were isothermal at $40{ }^{\circ} \mathrm{C}$ for 5 minutes, non-isothermal from $40{ }^{\circ} \mathrm{C}$ to $900{ }^{\circ} \mathrm{C}$, at heating rate of 15 ${ }^{\circ} \mathrm{C} / \mathrm{min}$ and air flow rate of $20 \mathrm{ml} / \mathrm{min}$.

\subsection{Kinetic analysis}

The combustion kinetics was explained as a twostage reaction scheme. First, the fuel changed to char and gas; second, the char to gas and ash (Gil et al., 2010; Shen et al., 2009). Such reaction is governed by the law of mass action (Equation 1) and Arrhenius Equation 2.

$$
\begin{aligned}
\frac{d x}{d t} & =k f(x) \\
k & =A e^{-E a / R T}
\end{aligned}
$$

where $\mathrm{f}(\mathrm{x})$ is the model for the reaction mechanism; $\mathrm{k}$ is the rate constant; $\mathrm{A}$ is the pre-exponential factor 
$\left(\mathrm{min}^{-1}\right) ; \mathrm{E}_{\mathrm{a}}$, is the activation energy $\left(\mathrm{kJ} \cdot \mathrm{mol}^{-1}\right) ; \mathrm{R}$ is the universal gas constant $\left(8.314 \mathrm{~J} \cdot \mathrm{K}^{-1} \cdot \mathrm{mol}^{-1}\right)$; $\mathrm{T}$ is temperature $(\mathrm{K})$; $\mathrm{t}$ is time (minutes); and $x$ is mass fraction - Equation 3.

$$
x=\left(m_{0}-m_{t}\right) /\left(m_{0}-m_{f}\right)
$$

where $m_{0}$ is the initial mass; $m_{t}$ is the mass at time $\mathrm{t}$; and $\mathrm{m}_{\mathrm{f}}$ is the final mass of the sample. For constant rate of heating, $\beta=\mathrm{dT} / \mathrm{dt}\left(\mathrm{K}_{\mathrm{min}}{ }^{-1}\right)$. Equation 1 was re-written as Equation 4 .

$$
\frac{d x}{f(x)}=\frac{k}{\beta} d T
$$

The temperature dependence of the rate constant was introduced by replacing $\mathrm{k}$ in Equation 4 with the Arrhenius equation, to give Equation 5.

$$
\frac{d x}{f(x)}=\frac{1}{\beta}\left(A e^{-\frac{E}{R T}}\right) \cdot d T
$$

An integration of Equation 5 between the limits $0-\mathrm{x}$, and $\mathrm{T}_{0}-\mathrm{T}$ yielded Equation 6.

$$
\ln \left(\frac{g(x)}{T^{2}}\right)=\ln \left(\frac{A R}{\beta E\left(1-\frac{2 R T}{E}\right)}\right)-\frac{E}{R T}
$$

The function in $g(x)$, Equation 6. depends on the mechanism in Table 3 that controls the combustion, the size, and shape of particles (Moon et al., 2013). This basic function was used for the kinetic study by fitting $\mathrm{g}(\mathrm{x})$ in a graph of $\ln \left[\mathrm{g}(\mathrm{x}) / \mathrm{T}^{2}\right]$ versus $1 / \mathrm{T}$. The 01, 02 and 03 represent first, second and third order reaction, $\mathrm{R} 2$ and $\mathrm{R} 3$ indicates phase boundary, while D1- D4 show different dimensions of diffusion. The reaction mechanism was obtained from the plot with the best straight line, while the activation energy $E_{a}$, was derived from the slope, $\left(-E_{a} / R\right)$. By determining the temperature at which $\mathrm{m}_{\mathrm{t}}=\left(\mathrm{m}_{\mathrm{o}}\right.$ - $\mathrm{m}_{\mathrm{f}}$ )/2, A was calculated (Khawam et al., 2006).

Table 3: Basic expressions for $\mathbf{g}(\mathbf{x})$.

\begin{tabular}{lcc}
\hline \multicolumn{1}{c}{ Mechanism } & Symbol & Model $g(x)$ \\
\hline \multirow{2}{*}{ Reaction order } & 01 & $\ln [1 /(1-\mathrm{x})]$ \\
& 02 & $1 /(1-\mathrm{x})$ \\
Phase bound- & R2 & $1 /(1-\mathrm{x})^{2}$ \\
ary & R3 & $1-(1-\mathrm{x})^{1 / 2}$ \\
& D1 & $1-(1-\mathrm{x})^{1 / 3}$ \\
Diffusion & D2 & $(1-\mathrm{x}) \ln (1-\mathrm{x})+\mathrm{x}$ \\
& D3 & {$\left[1-(1-\mathrm{x})^{1 / 3}\right]^{2}$} \\
& D4 & $1-2 \mathrm{x} / 3-(1-\mathrm{x})^{2 / 3}$ \\
\hline & D conversion, R2, R3 $=$ circular, spherical sur- \\
faces.1-D, 2-D, 3-D = one, two, three dimensions
\end{tabular}

\subsection{Combustion characteristics of composites}

Four stages were identified: de-watering (A), de-volatilisation and burning (B), char combustion (C), and burn-out (D). The ignition temperature ( $\mathrm{T}$ ig), the peak temperature $\left(\mathrm{T}_{h}\right)$, rate of combustion $(\mathrm{dm} / \mathrm{dt})$ at maximum and the burnout temperature ( $\mathrm{T}_{\mathrm{b}}$ ) were derived (Xiumin et al., 2001b). The combustion parameters were obtained by constructing a tangent on the TGA curve along the de-volatilisation stage $B$, and another tangent along the char stage (C) (Niu, Han; Lu, 2011). The point of intersection of these two tangents traced to the x-axis was $\mathrm{T}$ ig. Another line was constructed along the mass stabilisation stage $D$, then where the line intersected the line drawn along stage (C) was considered as burn-out. The $\mathrm{dm} / \mathrm{dt}$ max and $\mathrm{dm} / \mathrm{dt}$ mean were obtained from the actual thermogravimetricdifferential thermogravimetric analysis data. Overall combustion performance was assessed by the determination of combustion property (also known as S-value, -factor or -index). This represents the comprehensive combustion property (CCP), calculated using Equation 7.

$$
\begin{aligned}
& S=\frac{R}{E} \frac{d}{d T}\left(\frac{d m}{d t}\right)_{T=T_{i g}} \frac{d m / d T_{\text {max }}}{d m / d t_{T=T_{i g}}} \frac{d m / d T_{\text {mean }}}{T_{\mathrm{h}}}= \\
& {\left[\frac{\left(\frac{d m}{d t}\right)_{\text {max }}\left(\frac{d m}{d t}\right)_{\text {mean }}}{\left(T^{2}\right)_{\text {ig }}\left(T_{\mathrm{h}}\right)}\right]}
\end{aligned}
$$

where $\mathrm{E}=$ activation energy; $(\mathrm{dm} / \mathrm{dt}) \max =$ maximum burning velocity (rate); $(\mathrm{dm} / \mathrm{dt})$ mean = mean burning velocity; $\mathrm{T}$ ig = ignition temperature; and $\mathrm{T}$ $\mathrm{h}=$ burnout temperature. The component $\frac{\mathrm{R}}{\mathrm{E}}$ represents the reactivity and a small value for $\mathrm{E}$ implies very reactive fuel, while $(\mathrm{dm} / \mathrm{dt}) /(\mathrm{dm} / \mathrm{dt} T=\mathrm{T} \mathrm{ig})$ is rate of change of mass at the ignition, and $(\mathrm{dm} / \mathrm{dt}$ mean)/ $\mathrm{T} h$ is the ratio of mean rate and burnout temperature. The S-value measures the ease of ignition, rate, and burn-out; and high index describes an improvement in combustion (Niu et al., 2011).

\section{Results and discussion}

The rate of combustion of feedstocks, Figure 3, with increase in charcoal and microalgae biomass in the composites, Figure 4, are as shown.

\subsection{TGA results}

Microalgae biomass was more reactive (Figure 3) than the charcoal. Both materials improved the rate of combustion (Figure 4). The two materials lowered the ignition, peak, and burn-out temperatures. However, the rate was unsymmetrical with an increased amount of charcoal. This suggested two thermal events for instance in a composite with $70 \%$ coal, $30 \%$ charcoal, and $0 \%$ microalgae represented as 70C-30Ch-00A. For an increased amount, such as $15 \%$ microalgae biomass, $75 \mathrm{C}-10 \mathrm{Ch}-15 \mathrm{~A}$, the rate remained symmetrical, which was an indi- 


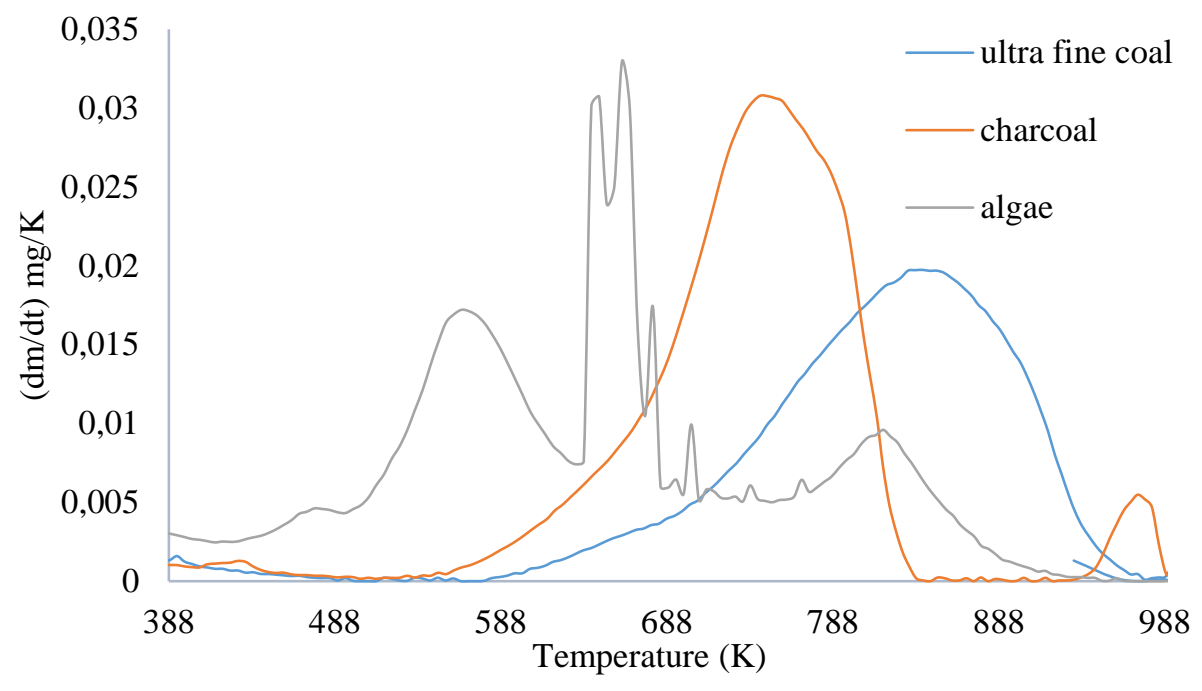

Figure 3: The rate of combustion of feedstocks.

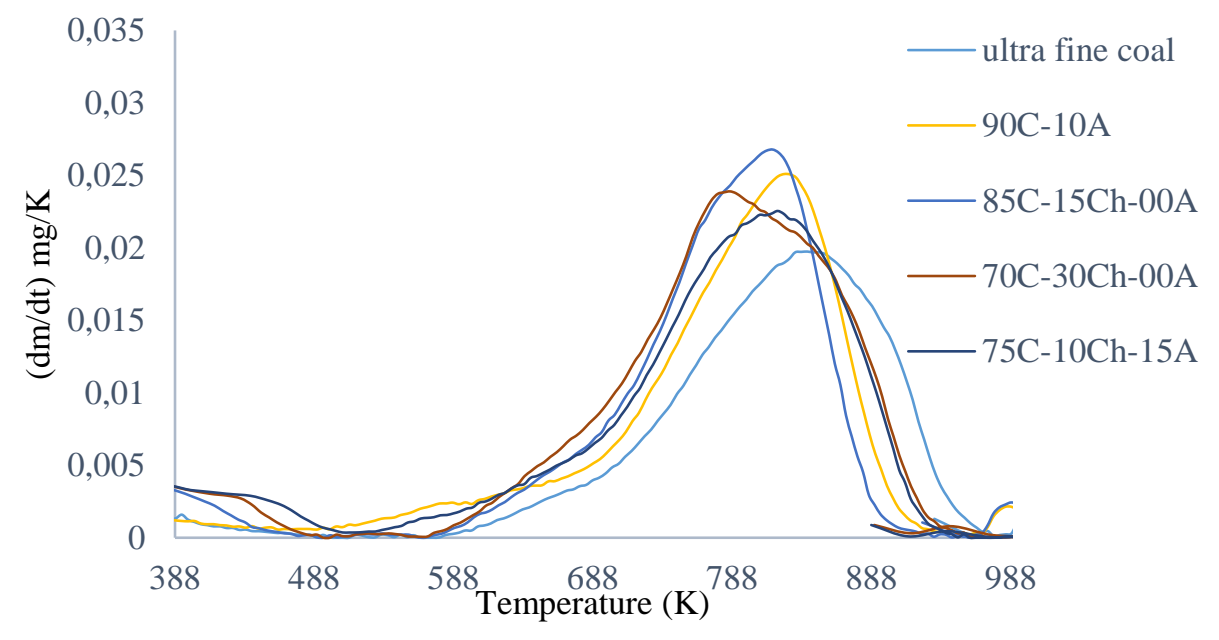

Figure 4: The rate of combustion with increase in charcoal and microalgae.

cation of a single combustion event. The temperature range in Table 4 , for feedstock, showed that microalgae had extra two stages. With exception of microalgae biomass, the ignition temperatures $(\mathrm{T}$ ig), Table 5, corresponds closely with the initial part of stage 3 , Table 4.

Microalgae biomass ignited earlier (Table 5), than the discard ultra-fine coal. The coal had delayed burn-out compared with other samples. The highest combustion rate of 11.10 and S-value of 15.48 for biomass, in Table 5, was an indication of best performance among the materials. The S-values greater than 2 indicate good general combustion performance (López-González et al., 2014, Wang et al., 2009, Plis et al. 2016). The biomass recorded the highest peak of combustion rate and Svalue, which is expected to improve combustion of the composite.

\subsection{Kinetic model}

Since the aim was to identify the main thermal events rather than the actual reaction mechanism, only the first-order model (01) $\ln \left[\ln 1 /(1-\mathrm{x}) / \mathrm{T}^{2}\right]$ was fitted. When the 01 model was fitted for discard ultra-fine coal, the correlation, $\mathrm{R}=0.9962$, produced a straight-line, indicating that one thermal event obtained in Figure 5 was probably correct.

When 01 was fitted for charcoal (Figure 6) there appeared to be two closely spaced thermal events. The first event fitted the first order (01) model $(\mathrm{R}=$ 0.9996), while the second did not, as indicated by the curvature and $\mathrm{R}=0.9874$ in Figure 6 .

The first order model of $\ln (\mathrm{g}(\mathrm{x})) / \mathrm{T}^{2}$ for microalgae (Figure 7) showed about five thermal events. Only the first two events fitted first order model, $\mathrm{R}^{2}$ $=0.9994$ and 0.997 , respectively. The $\mathrm{R}^{2}=0.926$, 0.977 and 0.9401 describe other pathways i.e. 
Table 4: Combustion stages and temperature range.

\begin{tabular}{cccc}
\hline \multicolumn{4}{c}{ Temperature range $(K)$} \\
\hline Stages & Coal & Charcoal & Microalgae \\
\hline A & $300-578$ & $300-541$ & $300-425$ \\
B & $578-665$ & $541-597$ & $425-490$ \\
C1 & $665-976$ & $597-834$ & $490-624$ \\
C2 & NA & NA & $624-760$ \\
C3 & NA & NA & $760-869$ \\
\hline A = drying, B = pyrolysis, C = char combustion, NA = not applicable &
\end{tabular}

Table 5: The combustion properties of the feedstocks.

\begin{tabular}{cccc}
\hline Combustion properties & Coal $(\mathrm{C})$ & Charcoal $(\mathrm{Ch})$ & Microalgae $(\mathrm{A})$ \\
\hline $\mathrm{T}_{\mathrm{ig}}(\mathrm{K})$ & 669.00 & 601.00 & 443.00 \\
$\mathrm{~T}_{\mathrm{b}}(\mathrm{K})$ & 1048.00 & 997.00 & 950.00 \\
$(\mathrm{dm} / \mathrm{dt})_{\text {mean }}$ & 2.60 & 3.30 & 2.60 \\
$(\mathrm{dm} / \mathrm{dt})_{\max }$ & 5.70 & 10.30 & 11.10 \\
$\mathrm{~T}_{\mathrm{h}}(\mathrm{K})$ & 842.03 & 739.89 & 661.06 \\
S-value $\left(\mathrm{x} \mathrm{10} 0^{8}\right)$ & 3.16 & 9.44 & 15.48 \\
Ash $(\%)$ & 24.76 & 4.02 & 3.24 \\
\hline
\end{tabular}

$\mathrm{T}_{\mathrm{Ig}}=$ ignition temperature, $\mathrm{T}_{\mathrm{b}}=$ burn out temperature, $[\mathrm{dm} / \mathrm{dt}]_{\text {mean }}=$ mean rate; $\mathrm{T}_{\mathrm{h}}=$ temperature at $[\mathrm{dm} / \mathrm{dt}]_{\max }$ i.e. maximum rate, $\mathrm{C}=$ discard coal

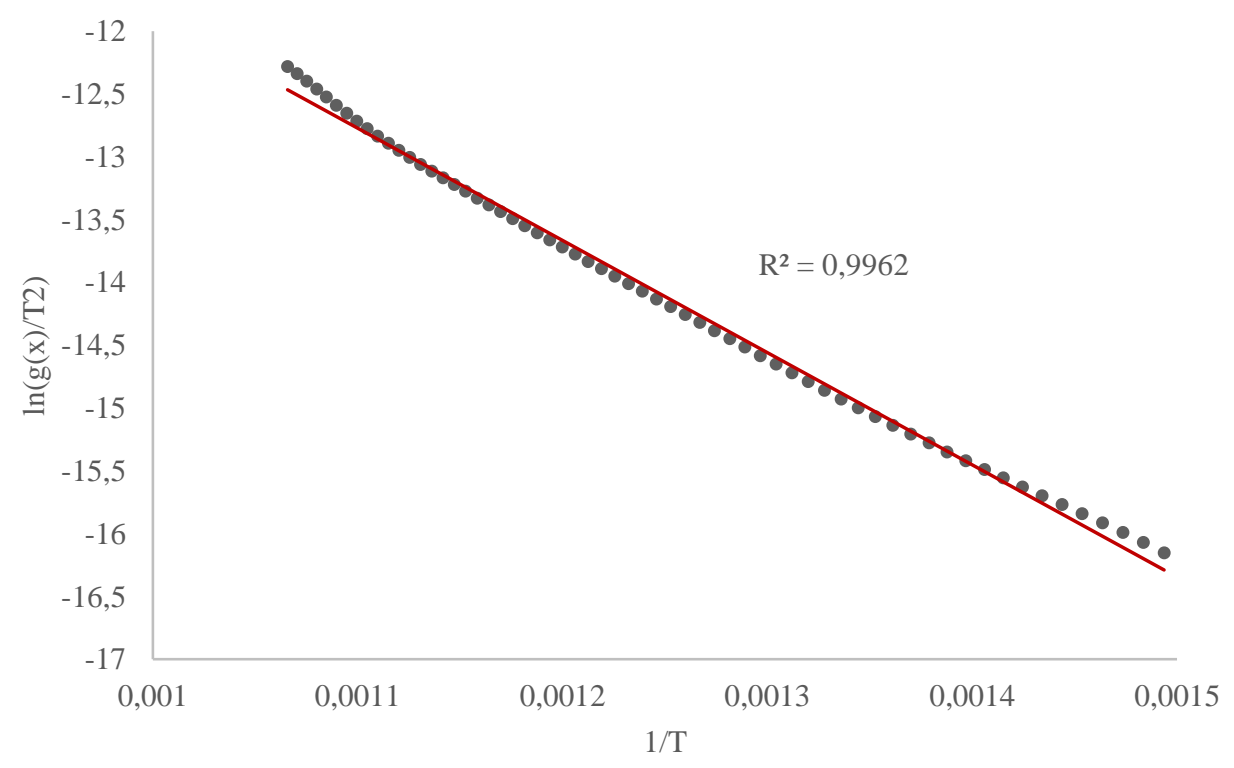

Figure 5: The first order model for discard ultra-fine coal C. 


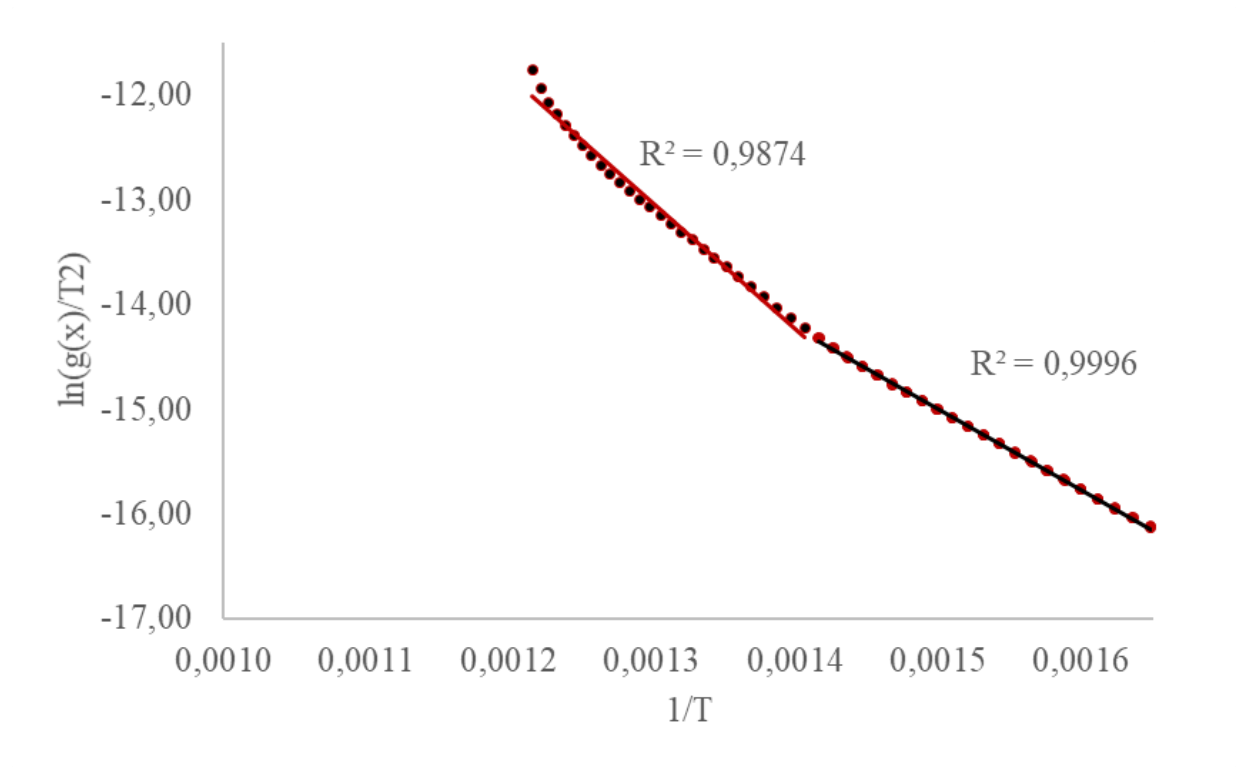

Figure 6: The first order model for charcoal

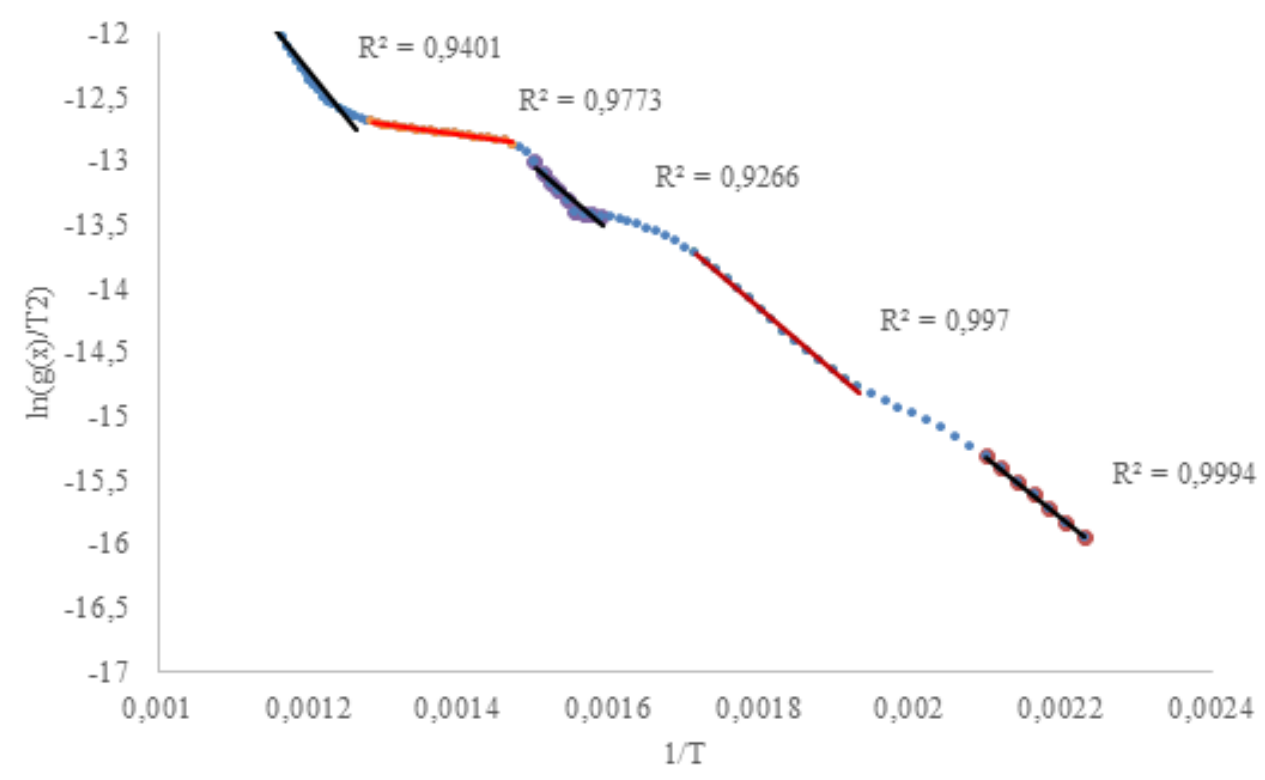

Figure 7: The first order model for microalgae biomass.

mechanisms followed by the combustion of microalgae biomass, Figure 3 section 3.1 .

The $85 \%$ coal $-15 \%$ charcoal and $70 \%$ coal $-30 \%$ charcoal fitted the 01 reaction model (Figure 8), with good straight-lines, $\mathrm{R}^{2}=0.9951$ and 0.9987 .

For the discard ultra-fine coal-microalgae, there was no indication of multiple thermal events (Figures 5 and 6). Fitting of 01 model for $90 \mathrm{C}-10 \mathrm{~A}$ and $80 \mathrm{C}-20 \mathrm{~A}$ showed that it was not first order kinetics (Figures 10-11), as in the coal.

\subsection{Combustion characteristics for composites}

The composites were described as $\mathrm{x} \mathrm{C}-\mathrm{y} \mathrm{Ch}-\mathrm{z} \mathrm{A}$, where $\mathrm{C}=$ coal, $\mathrm{Ch}=$ charcoal, $\mathrm{A}=$ microalgae, and $\mathrm{x}$, $\mathrm{y}$ and $\mathrm{z}=$ ratios (\%) with the thermochemical properties shown in Table 6.
The addition of microalgae biomass or charcoal (Table 6) increased the response surface, i.e., Svalue. The derivation of response surface with mixture model, Equation 8, and its validation with multiple regression provided the result shown in Table 7.

$$
\begin{aligned}
& Y=\beta_{1} X_{1}+\beta_{2} X_{2}+\beta_{3} X_{3}+\beta_{4} X_{1} X_{2}+\beta_{5} X_{1} X_{3}+ \\
& \beta_{6} X_{2} X_{3}+\beta_{7} X_{1} X_{2} X_{3}+\varepsilon
\end{aligned}
$$

where $X=$ the main effects, i.e., $\mathrm{X}_{1}, \mathrm{X}_{2}, \mathrm{X}_{3}=$ proportions of discard ultra-fine coal, charcoal, and microalgae biomass respectively; $X_{i} \mathrm{X}_{j}=$ two-factor interactions; $\mathrm{X}_{i} X_{j} \mathrm{X}_{k}=$ three-factor interaction; and $\varepsilon=$ experimental error. 


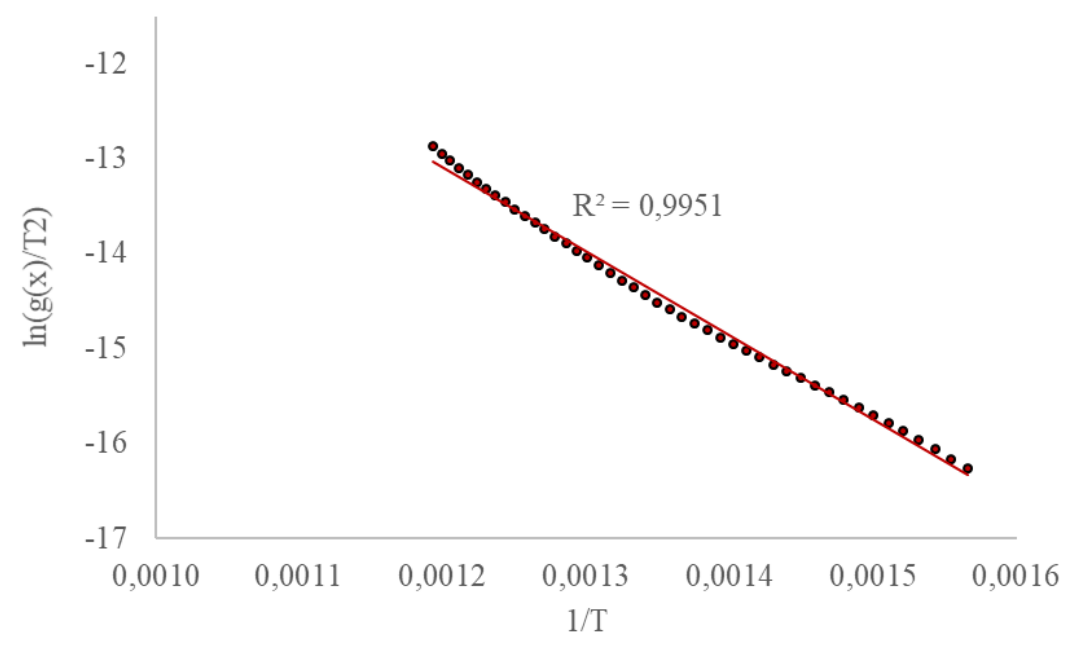

Figure 8: The first order model for $85 \mathrm{C}-15 \mathrm{Ch}$, where $\mathrm{C}=$ coal and $\mathrm{Ch}=$ charcoal.

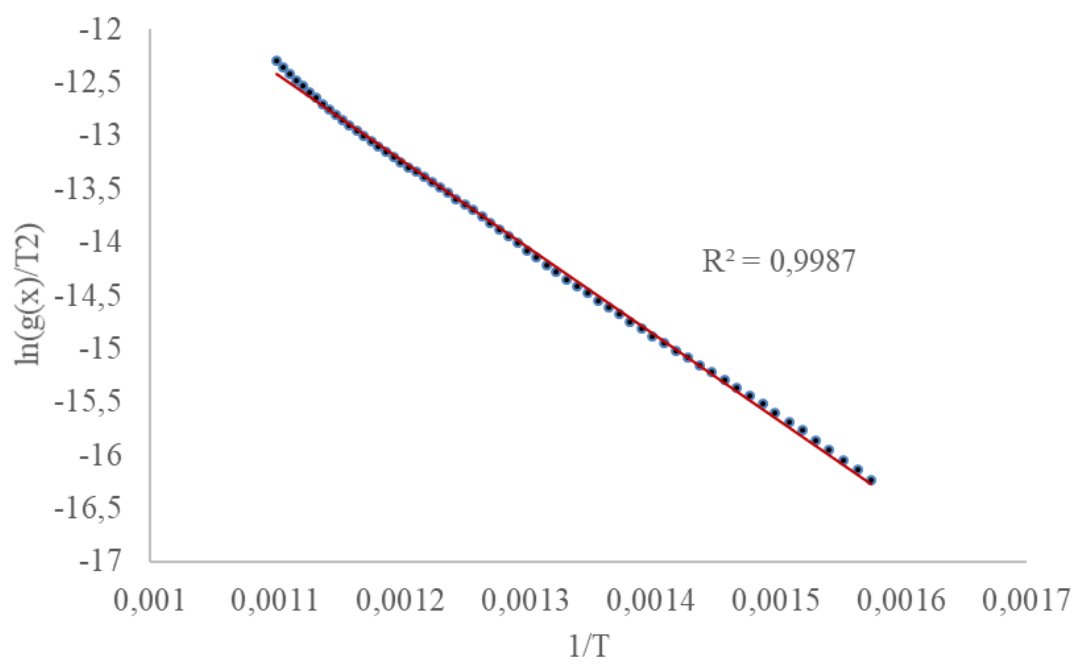

Figure 9: The first order model for the $70 \mathrm{C}-30 \mathrm{Ch}$, where $\mathrm{C}=\mathrm{coal}$ and $\mathrm{Ch}=$ charcoal.

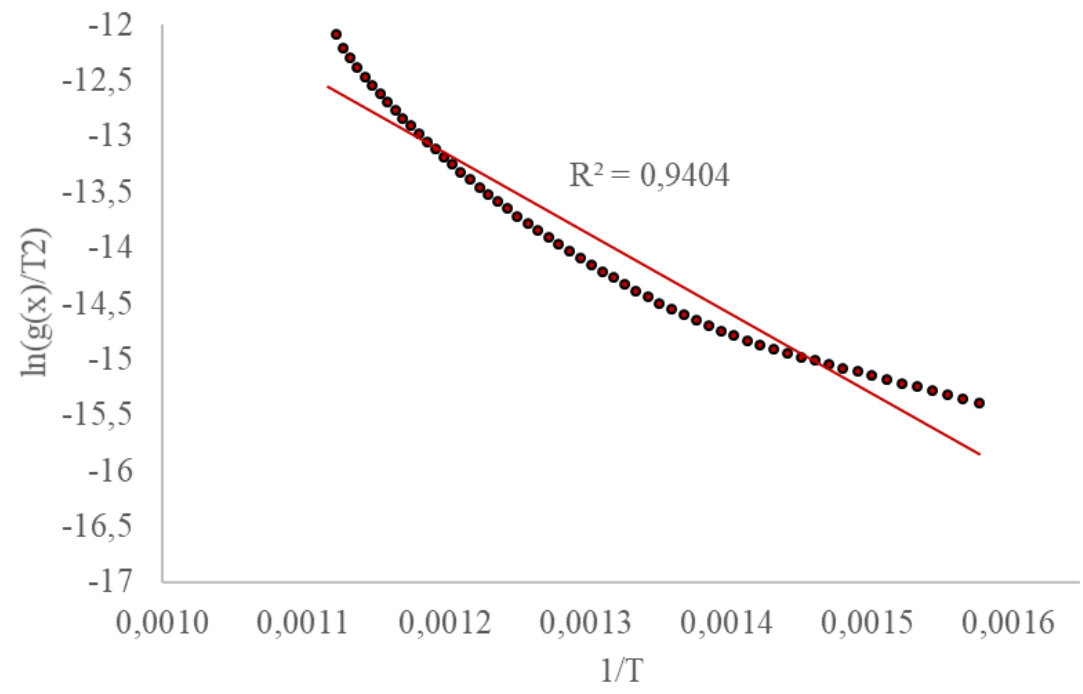

Figure 10: The first order model for $90 \mathrm{C}-10 \mathrm{~A}$, where $\mathrm{C}=$ coal and $\mathrm{A}=$ microalgae biomass. 


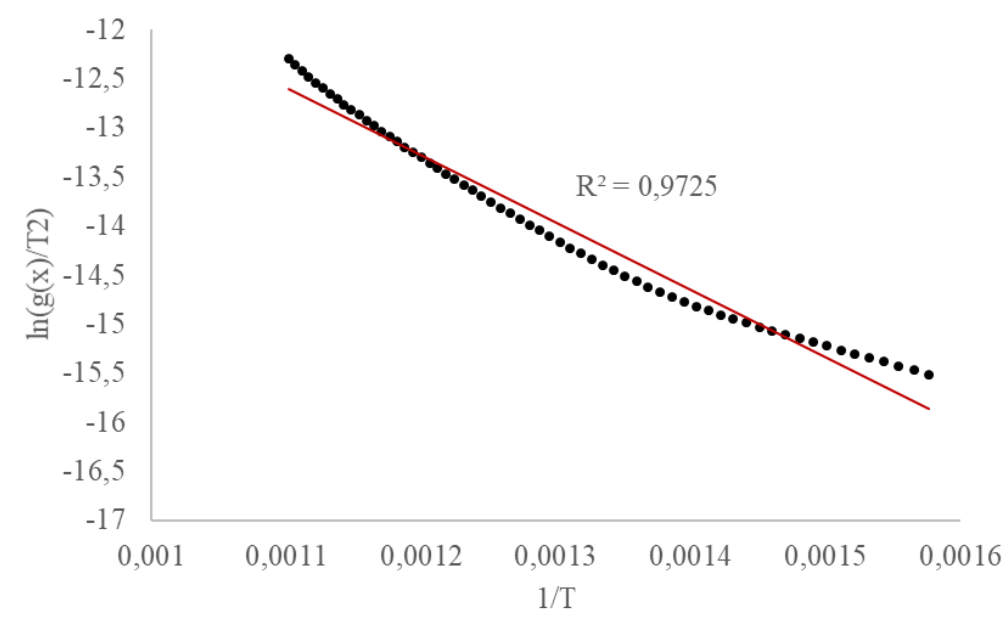

Figure 11: The first order model for $80 \mathrm{C}-20 \mathrm{~A}$, where $\mathrm{C}=$ coal and $\mathrm{A}=$ microalgae biomass.

Table 6: Thermochemical properties of composites.

\begin{tabular}{ccccccccc}
\hline No. & Fuel & $T_{i g}(K)$ & $T_{b}(K)$ & $D T G_{\operatorname{mean}}$ & $D T G_{\max }$ & $T_{h}(K)$ & $S x 10^{8}$ & Ash \\
\hline 1 & 100C-00Ch-00A & 669.00 & 1048.00 & 2.60 & 5.70 & 842.03 & 3.16 & 24.76 \\
2 & 90C-00Ch-10A & 628.00 & 1035.00 & 2.60 & 7.10 & 821.29 & 4.52 & 20.69 \\
3 & 85C-15Ch-00A & 634.00 & 1030.00 & 2.80 & 7.70 & 808.67 & 5.21 & 20.31 \\
4 & 85C-15Ch-00A & 634.00 & 1030.00 & 2.80 & 7.80 & 808.67 & 5.28 & 20.31 \\
5 & 100C-00Ch-00A & 669.50 & 1043.83 & 2.60 & 4.81 & 846.32 & 3.00 & 24.72 \\
6 & 80C-00Ch-20A & 629.00 & 954.00 & 3.20 & 6.30 & 803.43 & 5.34 & 22.60 \\
7 & 80C-00Ch-20A & 629.00 & 954.00 & 3.20 & 6.30 & 798.99 & 5.51 & 22.60 \\
8 & 70C-20Ch-10A & 629.00 & 1090.00 & 2.40 & 6.20 & 803.51 & 3.45 & 19.49 \\
9 & 70C-30Ch-00A & 629.00 & 1099.00 & 2.50 & 6.60 & 777.79 & 3.79 & 14.73 \\
10 & 70C-10Ch-20A & 624.00 & 1030.00 & 2.50 & 6.10 & 807.15 & 3.80 & 22.58 \\
11 & 75C-20Ch-05A & 629.00 & 1086.00 & 2.60 & 6.40 & 807.86 & 3.87 & 16.60 \\
12 & 75C-20Ch-05A & 629.00 & 1086.00 & 2.60 & 6.40 & 807.86 & 3.87 & 16.60 \\
13 & 80C-10Ch-10A & 634.00 & 1094.00 & 2.50 & 6.50 & 807.65 & 3.70 & 17.49 \\
14 & 70C-30Ch-00A & 629.00 & 1099.00 & 2.50 & 6.60 & 790.78 & 3.79 & 14.73 \\
\hline
\end{tabular}

$\mathrm{C}=$ discard ultra-fine coal, $\mathrm{Ch}=$ charcoal, $\mathrm{A}=$ microalgae biomass, $\mathrm{S}=\mathrm{S}$-value (C.C.C), $\mathrm{x} 10^{8}$, Ash content in $\%, \mathrm{~T}_{\mathrm{ig}}=$ ignition; $\mathrm{T}_{\mathrm{b}}=$ burn out; $\mathrm{DTG}=$ rate of combustion, $[\mathrm{dm} / \mathrm{dt}]$ mean $=$ mean velocity; $\mathrm{T}_{\mathrm{h}}=$ Temperature maximum, and $[\mathrm{dm} / \mathrm{dt}] \max =$ Maximum rate.

Table 7: Summary of regression for S-values.

\begin{tabular}{cccccc}
\hline Coefficients & Factor & Estimated $(b)$ & Std. error & $t$-value & $p$-value \\
\hline b1 & Coal (C) & 3.06 & 0.0646 & 47.4402 & 0.0000 \\
b2 & Charcoal (Ch) & -50.69 & 2.5188 & -20.1235 & 0.0000 \\
b3 & Algae (A) & -16.71 & 6.3377 & -2.6362 & 0.0336 \\
b4 & C-Ch & 80.37 & 3.5353 & 22.7345 & $<0.0001$ \\
b5 & C-A & 39.17 & 7.9668 & 4.9161 & 0.0017 \\
b6 & Ch-A & 701.03 & 84.1754 & 8.3283 & $<0.0001$ \\
b7 & C-Ch-A & -1069.49 & 113.4336 & -9.4283 & $<0.0001$ \\
\hline
\end{tabular}

Std. = standard, b1 - b7 = coefficients of interaction for coal, charcoal, microalgae biomass, coal-charcoal, coalmicroalgae, charcoal-microalgae, coal-charcoal-microalgae, respectively. 
The $\beta_{i}=$ regression coefficients estimated by least squares linear regression methods are given by Equation 9.

$$
b_{i}=\left(X^{t} X\right)^{-1} X^{t} y
$$

where $\mathrm{X}^{\mathrm{t}}=$ the transpose of the model matrix, $\mathrm{X} ;\left(\mathrm{X}^{\mathrm{t}}\right.$ $X)^{-1}=$ the inverse of the product matrix $\left(X^{t} X\right) ; y=$ the column vector of experimental responses; and $b_{i}=$ the column vector of model parameters (effects). The linear least squares fitting of Equation 8 to the $\mathrm{S}$-value showed positive coefficients for three 'two-way' interactions, $\mathrm{C}-\mathrm{Ch}, \mathrm{C}-\mathrm{A}$, and $\mathrm{Ch}-\mathrm{A}$, indicating that either charcoal or microalgae biomass improved the S-value (see Table 7).

For the 'three-way' interaction, C-Ch-A, b = 1069.49, there was an antagonistic interaction, which implied that either charcoal or microalgae could be used but not both with discard ultra-fine coal. That is, only charcoal, or microalgae biomass alone could be blended with discard ultra-fine coal. The analysis of variance for the predicted model (Bosma, 2012b; Bosma, 2012a) that contains the terms in Table 7 is described in Equation 10.

$$
\begin{aligned}
& \tilde{Y}=\beta_{1} X_{1}+\beta_{2} X_{2}+\beta_{3} X_{3}+\beta_{4} X_{1} X_{2}+ \\
& \beta_{5} X_{1} X_{3}+\beta_{6} X_{2} X_{3}+\beta_{7} X_{1} X_{2} X_{3}
\end{aligned}
$$

where $\tilde{Y}=$ the predicted CCP or S-value, and serves as a prediction formula of the estimated response surface, S-values for composites of similar feedstocks within the experimental domain. A measure of the quality of the prediction was given by the coefficient $\mathrm{R}^{2}=0.9936$ (see Table 8), which explained $99.36 \%$ of the variations in the observed data. A substitution of the estimated coefficients into the model (Equation 10) provided the predicted Svalue with a prediction formula given by Equation 11.

$\hat{\mathrm{S}}=3.06 \mathrm{C}-50.69 \mathrm{Ch}-16.71 \mathrm{~A}+80.37 \mathrm{C} . \mathrm{Ch}+$

39.17C. A + 701.03Ch. A - 1069.49C. Ch. A.
The model validation of the predicted response is summarised in Table 8.

The model fits $(\mathrm{p}<0.0001)$ the data very well, correlation $\mathrm{R}^{2}=0.9936$. There is no indication of any lack-of-fit in the model since the $p$-value for lack-of-fit $>0.1$. The standard residual on normal probability scale did not show deviation from linearity. All the data points were normally distributed, with no outlier. The predicted values on the standardised residuals, as described by outlier t-plot, were evenly distributed, which indicated that the model fits. Also, the observed versus predicted CCC or S-values indicated that the proposed model fitted the real combustion process. The linear regression trend line has a gradient of one, with all the observed S-values within the 95\% prediction interval. The model validation plot indicated that the model fitted the observed combustion. So, the model (Equation 11) could be used for prediction of CCC or S-values, evaluation of combustion properties, and mass of components for Coalgae. The variation in comprehensive combustion characteristics, i.e., response surface was interpreted relative to proportions of components. In this way, the influence of charcoal, microalgae biomass and both on the coal was studied. The Pareto chart of $t$-values for the interaction coefficients for variable S-value showed 26.8922, 4.5199, 3.72350, 3.6872, 3.6783, and 3.56861 for coal, charcoal, charcoal-algae, coalalgae, coal-charcoal and algae respectively. This indicated that the impact of microalgae $\left(\mathrm{C}^{*} \mathrm{~A}=\right.$ $3.6872)$ was more, relative to charcoal $\left(\mathrm{C}^{*} \mathrm{Ch}=\right.$ 3.6783). Microalgae biomass improved combustion more than charcoal. This reason, coupled with binding property, made it an option for Coalgae production. The derivation and validation of the predicted model allowed for estimation of the best fuel in terms of kinetics and the response surface. Finding the maximum S-value was carried out using the build-in optimisation function with the combinations in Table 9 as starting points for the iterative calculation.

Table 8: Analysis of variance (ANOVA) - Response surface model for S-value.

\begin{tabular}{lccccc}
\hline $\begin{array}{c}\text { Source of } \\
\text { variation }\end{array}$ & $\begin{array}{c}\text { Sum of } \\
\text { squares }\end{array}$ & $\begin{array}{c}\text { Degrees of } \\
\text { freedom }\end{array}$ & $\begin{array}{c}\text { Mean } \\
\text { square }\end{array}$ & F-value & Prob. $>$ F \\
\hline Model & 9.2451 & 6 & 1.5408 & 181.16 & $<0.0001$ \\
Residual & 0.0595 & 7 & 0.0085 & - & - \\
Lack of fit & 0.0310 & 2 & 0.0154 & 2.71 & 0.1596 \\
Pure error & 0.0286 & 5 & 0.0057 & - & - \\
Cor. total & 9.3046 & 13 & - & - & - \\
\hline R-Squared & \multicolumn{5}{c}{0.9936} \\
\hline Cor. = correction, Prob. = probability, F = statistics, testing equality of means \\
\hline
\end{tabular}


Table 9: Starting blend combinations for optimisation.

\begin{tabular}{ccc}
\hline Coal & Charcoal & Microalgae \\
\hline 0.95 & 0.03 & 0.03 \\
0.84 & 0.11 & 0.05 \\
0.70 & 0.16 & 0.14 \\
0.73 & 0.21 & 0.06 \\
0.70 & 0.24 & 0.06 \\
0.82 & 0.16 & 0.02 \\
0.72 & 0.10 & 0.18 \\
0.72 & 0.09 & 0.18 \\
0.71 & 0.27 & 0.01 \\
0.85 & 0.14 & 0.01 \\
\hline
\end{tabular}

Each optimisation was run for 10 cycles indicated in Table 9 and two solutions were found, as shown in Table 10.

Table 10: Predicted composites for optimal S-values.

\begin{tabular}{ccccc}
\hline $\begin{array}{c}\text { Out- } \\
\text { comes }\end{array}$ & Coal & $\begin{array}{c}\text { Char- } \\
\text { coal }\end{array}$ & $\begin{array}{c}\text { Micro- } \\
\text { algae }\end{array}$ & $\begin{array}{c}\text { Predicted re- } \\
\text { sponse, S-value }\end{array}$ \\
\hline 1 & 0.80 & 0.00 & 0.20 & 5.38 \\
2 & 0.83 & 0.17 & 0.00 & 5.27 \\
\hline
\end{tabular}

The optimisation of composite confirmed that charcoal and microalgae improved the response, Svalue Table 10. Charcoal and microalgae should not be used together in one fuel because the interaction and predicted response for $\mathrm{C}^{*} \mathrm{~A}(\mathrm{~S}=5.38)$ is higher than $\mathrm{C}^{*} \mathrm{Ch}(\mathrm{S}=5.27)$. The outcome that $20 \%$ microalgae (dry-weight basis) is optimum on response surface should be interpreted with caution. Because, coal-charcoal was mixed dry and coal-microalgae by adsorption of the wet biomass. The composite was influenced by the particle size of coal and state of microalgae biomass. For example, the refrigerated microalgae absorbed less efficiently onto coal because of re-arrangement of surface-active groups on the biomass cell wall.

\section{Conclusions}

Microalgae biomass blended with discard ultra-fine coal upgraded the ignition temperature and rate of combustion. An optimal value of $20 \%$ microalgae reclaimed about $80 \%$ ultra-fine coal at $\mathrm{S}$-value of 5.32. The biomass, unlike $17 \%$ charcoal, sequestrates $\mathrm{CO}_{2}$ in a photo bio-reactor, thereby avoiding emissions. The interaction between the discard ultra-fine coal and microalgae biomass was synergistic. The combustion of composite, i.e. Coalgae, was not controlled by the first order reaction mechanism like the coal. Combustion of Coalgae required detailed kinetic explanation. The Coalgae could be fired as single 'coal and biomass' fuel, instead of combusting only coal to produce heat and electricity.

\section{Patent numbers}

- Patent 1: Upgrading coal fines using microalgae - PCT/IB2014/061295

- Patent 2: Carbonaceous materials US20160289567A1

\section{Acknowledgements}

Acknowledgements to the Department of Science and Technology and Technology Innovation Agency for funding the research; and Jacob Bosma for the statistical data analysis.

\section{Author roles}

Vitus 0. Ejesieme conducted the experiments and prepared this manuscript. The late Prof. Ben Zeelie made constructive inputs in the research design. Gary Dugmore and Nicole Vorster advised/contributed to the focus of the manuscript. (These three were the research supervisors.) Juan Riaza contributed with some interpretations and editing the text.

\section{References}

Chamber of Mines of South Africa. 2018. National Coal Strategy. Available at: www.chamberofmines.org.za (Accessed: 4 February 2020).

Antal, M. J. 2003. The art, science, and technology of charcoal production, Industrial \& Engineering Chemistry Research, 42: 1619-1640.

Arias B., Pevida C., Rubiera F. and Pis J.J. 2008. Effect of biomass blending on coal ignition and burnout during oxy-fuel combustion, Fuel, 87: 2753-2759. doi: http://dx.10.1016/j.fuel.2008.01.020.

Bakhtyar, B., Ibrahim Y., Alghoul MA., Aziz N., Fudholi A. and Sopian K. 2014. Estimating the $\mathrm{CO}_{2}$ abatement cost: substitute price of avoiding $\mathrm{CO}_{2}$ emission (SPAE) by renewable energy's feed in tariff in selected countries, Renewable and Sustainable Energy Reviews 35: 205-210. doi: https://doi.org/10.1016/j.rser.2014.04.016.

Baxter, L. 2005. Biomass-coal co-combustion : opportunity for affordable renewable energy, Fuel, 84: 1295-1302. doi: https://doi.org/10.1016/j.fuel.2004.09.023.

Baxter, L. 2010. Green energy and technology. Edited by Panagiotis Grammelis. Springer London Dordrecht Heidelberg New York. doi: http//:doi.10.1007/978-1-84996-393-0. 
Borowitzka, M. A. 1999. Commercial production of microalgae: ponds, tanks, tubes and fermenters, Journal of Biotechnology, 70: 313-321.

Bosma, J. 2012a. Bivariate regression for analysts, scientists and engineers, Port Elizabeth, South Africa.

Bosma, J. 2012b. Introduction to data analysis for analysts, scientists and engineers, Port Elizabeth, South Africa. BP Energy. 2018. BP Statistical review of World Energy 2018.

Bunt, J. R., Neomagus J.P. and Botha A.A. 2015. Reactivity study of fine discard coal agglomerates, Journal of Analytical and Applied Pyrolysis, 113: 723-728. doi: http//:doi.10.1016/j.jaap.2015.03.001.

Burhenne, L., Messmer J., Aicher T. and Laborie M. 2013. The effect of the biomass components lignin, cellulose and hemicellulose on TGA and fixed bed pyrolysis, Journal of Analytical and Applied Pyrolysis, 101: 177-184. doi: https://doi.org/10.1016/j.jaap.2013.01.012.

Campus, T. 2019. South Africa's mineral industry 2017/2018 -SAMI-. Pretoria. Available at: www.dmr.gov.za.

CarbonBrief. 2018. The carbon brief profile : South Africa, CarbonBrief's country profile series. Available at: https://www.carbonbrief.org/the-carbon-brief-profile-south-africa (Accessed: 4 February 2020).

Chen, C. Zhao, X., Yen, H., Ho, S. and Cheng, C. 2013. Microalgae-based carbohydrates for biofuel production, Biochemical Engineering Journal, 78: 1-10. doi: https://doi.org/10.1016/j.bej.2013.03.006.

David, P. 1995. The south african coal mining industry: a need for a more efficient and collaborative supply chain, Journal of Transport and Supply Chain Management, 5(12011)).

Demirba, A. 2003. Sustainable cofiring of biomass with coal, Energy Conversion and Management, 44(9): 1465-1479. doi: https://doi.org/10.1016/S0196-8904(02)00144-9.

Department of Energy. 2018. 2018 South African energy sector report. Pretoria. Available at: www.energy.gov.za.

Filippis, P. D., Caprariis B.D., Scarsella M. and Verdone N. 2015. Double distribution activation energy model as suitable tool in explaining biomass and coal pyrolysis behavior, Energies, 8: 1730-1744. doi: https://doi.org/10.3390/en8031730 .

Gil, M. V., Casal D., Pevida C., Pis J.J. and Rubiera F. 2010. Thermal behaviour and kinetics of coal/biomass blends during co-combustion, Bioresource Technology, 101(14): 5601-5608. doi: http://dx.doi.org/10.1016/j.biortech.2010.02.008.

James, G. S. 2005. Handbook of coal analysis. John Willey \& Sons Inc. New Jersey. 2005.

Joel, C. 2010. Combustion characteristics of biomass briquettes. University of Nottingham.

Jones, J. M. and Ross, A. B. 2017. Organic carbon emissions from the co-firing of coal and wood in a fixed bed combustor, Fuel, 195: 226-231. doi: https://doi.org/10.1016/j.fuel.2017.01.061.

Khawam, A. and Flanagan, D. R. 2006. Solid-state kinetic models : Basics and mathematical fundamentals: 110(35): 17315-17328. doi: https://doi.org/10.1021/jp062746a.

Lee, J., Kim D., Lee, J.P., Park, S.C., Koh J.H., Cho, H.S. and Kim, S.W. 2002. Effects of $\mathrm{SO}_{2}$ and $\mathrm{NO}_{\mathrm{x}}$ on growth of Chlorella sp. KR-1, Bioresource Technology, 82: 2-5.

Moon, C., Sung, Y., Ahn. S., Kim, T., Choi, G. and Kim, D. 2013. Effect of blending ratio on combustion performance in blends of biomass and coals of different ranks, Experimental Thermal and Fluid Science, 47: 232-240. doi: https://doi.org/10.1016/j.expthermflusci.2013.01.019.

Munzhedzi, R. and Sebitosi, A. B. 2009. Redrawing the solar map of South Africa for photovoltaic applications, Renewable Energy, 34: 165-169. doi: https://doi.org/10.1016/j.renene.2008.03.023.

Muzenda, E. 2014. Potential uses of South African coal fines, 3rd International Conference on Mechanical, Electronics and Mechatronics Engineering (ICMEME 2014): 37-39.

Niu, S., Han, K. and Lu, C. 2011. Characteristic of coal combustion in oxygen/carbon dioxide atmosphere and nitric oxide release during this process, Energy Conversion and Management, 52(1): 532-537. doi: https://doi.org/10.1016/j.enconman.2010.07.028.

P. Spolaore, C. Joannis-Cassan, E. and Duran, A. I. C. 2006. Commercial applications of microalgae, Journal of Bioscience and Bioengineering, 101: 201-211.

Packer, M. 2009. Algal capture of carbon dioxide; biomass generation as a tool for greenhouse gas mitigation with reference to New Zealand energy strategy and policy, Energy Policy, 37(9): 3428-3437. doi: https://doi.org/10.1016/j.enpol.2008.12.025.

Pirraglia, A., Gonzalez, R., Denig, J., Saloni, D. and Wright, J. 2012. Assessment of the most adequate pre-treatments and woody biomass sources intended for direct co-firing in the U.S., 7: 4817-4842.

Plis, A., Lasek, J. and Skawi, A. 2017. Kinetic analysis of the combustion process of Nannochloropsis gaditana microalgae based on thermogravimetric studies, Journal of Analytical and Applied Pyrolysis, 127(March):109-119. doi: https://doi.org/10.1016/j.jaap.2017.08.017.

Rafey, W. and Sovacool, B. K. 2011. Competing discourses of energy development : The implications of the Medupi coal-fired power plant in South Africa, Global Environmental Change, 21(3): 1141-1151. doi: https://doi.org/10.1016/j.gloenvcha.2011.05.005.

Rosemary, F. 2013. Coal geology, types, ranks and grades in coal, coke and carbon in the metallurgical industry.

Sami, M., Annamalai, K. and Wooldridge, M. 2001. Co-firing of coal and biomass fuel blends, Progess in Energy and Combustion Science, 27: 171-214. 
Shen, D. K., Gu, S., Luo, K.H., Bridgwater. A.V. and Fang, M.X. 2009. Kinetic study on thermal decomposition of woods in oxidative environment, Fuel. Elsevier Ltd, 88(6): 1024-1030. doi: https://doi.org/10.1016/j.fuel.2008.10.034.

Spolaore, P., Joannis-cassan, C., Duran, E., Isambert, A., Génie, L.D. and Paris E.C. 2006. Commercial applications of microalgae, Journal of Bioscience and Bioengineering, 101(2): 87-96. doi: https://doi.org/10.1263/jbb.101.87.

Syed, S., Qudaih, R., Talab, I. and Janajreh, I. 2011. Kinetics of pyrolysis and combustion of oil shale sample from thermogravimetric data, Fuel, 90(4): 1631-1637. doi: https://doi.org/10.1016/j.fuel.2010.10.033.

Xiumin, J., Chuguang, Z., Jianrong, Q., Jubin, L. and Dechang, L. 2001a. Combustion characteristics of super fine pulverized coal particle: $1100-1102$.

Xiumin, J., Chuguang, Z., Jianrong, Q., Jubin, L. and Dechang, L. 2001b. Combustion characteristics of super fine pulverized coal particles, Energy \& Fuels, 15: 1100-1102.

Yun, Y., Lee, S.B., Park, J.M. and Lee, C.I., 1997. Carbon dioxide fixation by algal cultivation using wastewater nutrients.

Zeelie, B. 2013. Carbonaceous fines beneficiation using micro-algae and related processes. South Africa: US Patent. 